\title{
Zadaniowy czas pracy
}

\author{
Task-based working time \\ dr hab. prof. UW Krzysztof Rączka \\ Uniwersytet Warszawski, Wydział Prawa i Administracji, \\ Katedra Prawa Pracy i Polityki Społecznej \\ k.raczka@wpia.uw.edu.pl
}

\begin{abstract}
Streszczenie Współczesne wymogi techniki, technologii i organizacji pracy, podyktowane autonomizacją coraz większej ilości rodzajów pracy, powodują zmianę zapotrzebowania na elastyczne systemy czasu pracy. Jednym z zasadniczych w tym kontekście rodzajem czasu pracy jest system zadaniowy, w ramach którego „gospodarzem” dobowego i tygodniowego czasu pracy w większym stopniu jest pracownik niż pracodawca. W zadaniowym czasie pracy pracownik bardziej podporządkowany jest przyporządkowanym mu zadaniom do wykonania niż bezpośrednio poleceniom kierownictwa pracy. Autor omawia ten coraz popularniejszy system czasu pracy, ze szczególnym uwzględnieniem orzecznictwa sądowego w tym zakresie.
\end{abstract}

Słowa kluczowe: zadaniowy czas pracy, system czasu pracy, rodzaj pracy, organizacja pracy, praca ponadwymiarowa, praca w godzinach nadliczbowych.

Summary The rise in number of autonomous occupations, resulting from technological and organizational issues, form an increasing need for flexible working time shaping. The only - in fact - working time system is the taskbased one, constituting an employee rather than employer the right to manage the daily and weekly working hours. This stems from a subordination to tasks and not to the directions of the employer. The hereby presented remarks tend to summarize all the aspects of the task-based working time system including its reflections in court decisions.

Keywords: task-based working time, working time system, work's specific, work organization, overtime work.

JEL: K31

Str. $18-21$

\section{Bibliografia}

Latos-Miłkowska (2008). Godzenie pracy zawodowej z życiem rodzinnym w przepisach o czasie pracy (work of balance). Praca $i$ Zabezpieczenie Spoleczne, (7).

Rączka, K. (2004). Systemy czasu pracy w znowelizowanym kodeksie pracy. Praca i Zabezpieczenie Spoleczne, (2).

Rycak, M. (2008). Prawne uwarunkowania elastycznego kształtowania czasu pracy w Polsce — propozycje zmian. Monitor Prawa Pracy, (1). 